\title{
China, the US, and the Law of the Sea
}

Sébastien Colin

\section{OpenEdition}

\section{Journals}

Electronic version

URL: https://journals.openedition.org/chinaperspectives/6994

DOI: 10.4000/chinaperspectives.6994

ISSN: 1996-4617

\section{Publisher}

Centre d'étude français sur la Chine contemporaine

\section{Printed version}

Date of publication: 1 June 2016

Number of pages: 57-62

ISSN: 2070-3449

\section{Electronic reference}

Sébastien Colin, "China, the US, and the Law of the Sea", China Perspectives [Online], 2016/2 | 2016,

Online since 01 June 2017, connection on 21 September 2021. URL: http://journals.openedition.org/ chinaperspectives/6994; DOI: https://doi.org/10.4000/chinaperspectives.6994 


\title{
China, the US, and the Law
}

\section{of the Sea}

\author{
SÉBASTIEN COLIN
}

T he South China Sea, a major transit area of international maritime traffic, is the scene of territorial and maritime claims expressed by the riparian states, including China but also Vietnam, the Philippines, Malaysia, Brunei, and Taiwan, and now represents one of the main stumbling blocks in the US-China bilateral relationship. Between October 2015 and mid-May 2016, a series of initiatives taken unilaterally by China on one side and the US on the other have greatly exacerbated the latent confrontation of the two powers in this maritime space.

Chinese initiatives have essentially consisted of fitting out the Paracel Islands and some recently reclaimed reefs of the Spratly archipelago with transport infrastructure. To this end, the Chinese Ministry of Transport has installed three lighthouses on the Spratly Islands: two on Cuarteron and South Johnson reefs on 9 October $2015^{(1)}$ and a third on Subi Reef on 6 April 2016. (2) On 2 January 2016, the spokeswoman for the Chinese Ministry of Foreign Affairs, Hua Chunying, confirmed completion of construction of an aerodrome on Fiery Cross Reef, which US satellite photos already showed in 2014. (3) This confirmation was followed on 6 January by the organisation of two civilian flight tests - one operated by China Southern Airlines and the other by Hainan Airlines - between the airport of Haikou, the provincial capital of Hainan, and the new Fiery Cross airfield. (4) Both tests may indicate future exploitation of this line on the heels of what the Chinese authorities already planned to do in the Paracel Islands. ${ }^{(5)}$ Finally, other actions such as the deployment of aircraft missile launchers on Woody Island on February $2016^{(6)}$ and anti-ship missiles in March ${ }^{(7)}$ seem to confirm the militarisation of the Paracels while leaving some doubt as to the establishment of a similar process in the Spratlys, which could lead, according to some observers, to the delimitation of an air defence identification zone in the South China Sea. ${ }^{(8)}$

These initiatives, which will probably be followed by others in the coming weeks and months, are the undisputed testimony of an increasingly firm will from China to increase its presence in the South China Sea in order to more effectively monitor this space and impose itself as the dominant power. China thus materialises a historically self-proclaimed sovereignty.

At the same time, Washington has allowed the US Navy to conduct three "Freedom of Navigation Operations" (FONOP). Three guided missile destroyers, the USS Lassen, on 27 October 2015, the USS Curtis Wilbur, on 30 January 2016, and the USS William P. Lawrence, on 10 May 2016, have respectively sailed within 12 nautical miles of Subi Reef, Triton Island, and Fiery Cross Reef, all claimed and occupied by China. ${ }^{(9)}$

The fact that the two countries answer each other through these actions is obvious. The deployment of missile launchers on Woody Island is clearly a response to the passage of the USS Curtis Wilbur near Triton Island, all the more so given that China undertook this deployment during the US-ASEAN special leaders' summit in Sunnylands, California, in the course of which Barack Obama reiterated that the US would continue to "fly, sail and operate wher- ever international law allows." The summit's joint statement, without clearly mentioning Chinese initiatives in the South China Sea, included calls for respecting "freedom of navigation and overflight" in the maritime areas as well as "non-militarization and self-restraint in the conduct of activities." (10)

In fact, a major concern in Washington is that this assertion of Chinese presence in the South China Sea will eventually threaten "freedom of navigation" and in the process, American strategic and economic interests. This concern is partly fuelled by China's official position regarding certain articles and clauses of the United Nations Convention on the Law of the Sea (UNCLOS) relating to the right of innocent passage through the territorial sea or in the conduct of activities by foreign military ships and aircraft in the exclusive economic zone (EEZ) of the coastal state. The three American FONOPs aimed to make clear that China's maritime claims are, from the

1. "China Completes Construction of Two Large Lighthouses in the South China Sea," Xinhua, 9 October 2015, http://news.xinhuanet.com/english/2015-10/09/c_134698039.htm (accessed on 6 April 2016).

2. Prashanth Parameswaran, "China Starts Operating New South China Sea Lighthouse on Subi Reef," The Diplomat, 6 April 2016, http://thediplomat.com/2016/04/china-starts-operating-new-southchina-sea-lighthouse-on-subi-reef (accessed on 6 April 2016)

3. "New Airfield to Boost Public Service in South China Sea: Chinese Official," Xinhua, 5 January 2016, http://news.xinhuanet.com/english/2016-01/05/c_134977219.htm (accessed on 6 April 2016).

4. "China Conducts Successful Test Flights at Newly-Built Airfield in South China Sea," Xinhua, 6 January 2016, http://news.xinhuanet.com/english/2016-01/06/C_134983993.htm (accessed on 6 April 2016).

5. Jesse Johnson, "China Plans to Begin Civilian Flights to, from Disputed South China Sea Isles," The Japan Times, 12 March 2016, www.japantimes.co.jp/news/2016/03/12/asia-pacific/china-set-tobegin-operating-civilian-flights-to-and-from-disputed-south-china-sea-nextyear/\#.VwSXksd8OUc (accessed on 6 April 2016).

6. Richard D. Fisher Jr, "China Deploys HQ-9 Surface-to-Air Missiles to Woody Island," IHS Jane's Defence Weekly, 17 February 2016, www.janes.com/article/58071/china-deploys-hq-9-surfaceto-air-missiles-to-woody-island (accessed on 6 April 2016).

7. Ankit Panda, "South China Sea: China Has Deployed Anti-Ship Missiles on Woody Island," The Diplomat, 26 March 2016, http://thediplomat.com/2016/03/south-china-sea-china-has-deployed-anti-ship-missiles-on-woody-island (accessed on 6 April 2016).

8. Jesse Johnson, "Beijing Missile Deployment Could Lay Groundwork for South China Sea ADIZ," The Japan Times, 18 February 2016, www.japantimes.co.jp/news/2016/02/18/national/beijing-missile-deployment-lay-groundwork-south-china-sea-adiz/\#.VwaFL32LTMx (accessed on 8 April 2016).

9. Gordon Lubold and Jeremy Page, "U.S. Navy Ship Sails Near Islands Claimed by China," The Wall Street Journal, 26 October 2015, www.wsj.com/articles/u-s-navy-ship-sails-near-islands-claimedby-china-1445908192 (accessed on 8 April 2016); Reuters (Washington), "US Warship Sails near Island Claimed by China in South China Sea," The Guardian, 30 January 2016, www.theguardian.com/world/2016/jan/30/south-china-sea-us-warship-triton-paracel-island (accessed on 6 April 2016); Euan Graham, "US Navy Carries Out Third FONOP in South China Sea," The Interpreter, 10 May 2016, www.lowyinterpreter.org/post/2016/05/10/US-Navy-carries-outthird-FONOP-in-South-China-Sea.aspx (accessed on 16 May 2016).

10. Jeff Mason and Bruce Wallace, "Obama, ASEAN Discuss South China Sea Tensions, But No Joint Mention of China," Reuters, 17 February 2016, www.reuters.com/article/us-usa-aseanidUSKCNOVP1F7 (accessed on 5 April 2016). For the text of the joint statement, see: The White House, "Joint Statement of the U.S.-ASEAN Special Leaders' Summit: Sunnylands Declaration, Sunnylands, California, February 15-16, 2016," https://www.whitehouse.gov/the-pressoffice/2016/02/16/joint-statement-us-asean-special-leaders-summit-sunnylands-declaration (accessed on 7 April 2016). 
perspective of the United States, "excessive" and "inconsistent" with UNCLOS. In response, some Chinese legal experts consider the unconditional attachment of the United States to "total" freedom of navigation to be primarily a tool for maintaining their "maritime hegemony." (11)

Thus, the Sino-US confrontation is also legal. What are the respective positions of China and the United States regarding UNCLOS, and what are the details of the main points of disagreement between the two countries? We will try here to provide answers to these questions on the basis of a corpus of texts mainly composed of legal books and articles on Chinese and American positions regarding the law of the sea, official statements, as well as the text of UNCLOS itself.

\section{China and the United States: What official positions regarding UNCLOS?}

The Chinese and US positions regarding UNCLOS appear paradoxical at first sight, with China having ratified the Convention while expressing several reservations on some articles and clauses, and the United States seeing itself as a defender of the correct implementation of the text but having not ratified it. It seems necessary to first clarify the context of the writing of UNCLOS, the imperfections of which fuel many divergent interpretations and enable contradictory implementation measures.

\section{The writing of the UNCLOS: Oppositions, compromises and lacunae}

As a real "Constitution for the oceans," (12) UNCLOS was concluded and opened to states' signatures on 10 December 1982 in Montego Bay, Jamaica, before coming into force on 16 November 1994. ${ }^{(13)}$ The adoption of the text, comprised of 17 parts and 320 articles and punctuated by nine annexes, marked the end of a very long negotiation that began in 1973. This text replaced several conventions that were signed in Geneva in 1958, and which developing countries considered too favourable to great maritime powers and industrialised countries. ${ }^{(14)}$ Aiming to legally define the maritime areas, as well as the rights and duties of states in these spaces in terms of navigation, exploitation of resources, and protection of the marine environment, the drafting of UNCLOS covered many geopolitical issues and was therefore at the heart of many disagreements between states and groups of states. The negotiation sessions were mainly the scene of fierce opposition between developing countries, anxious to extend their sovereignty and gain exclusive rights to the exploitation of resources in the largest maritime areas, and industrialised countries, defenders of a greater freedom of exploitation and navigation. These two visions were headed respectively by China and the United States.

In this context, the writing of the Convention required many compromises, as a result of which many items appear superficial, ambiguous, or incomplete. (15) Part V, devoted to the EEZ, is undoubtedly one of the best examples of this phenomenon. ${ }^{(16)}$ In its 1982 version, Part XI on the "international seabed zone" raised strong opposition from industrialised countries to the point that many of them refused to sign the text, including the US. (17) It was not until 28 July 1994, following a renegotiation of Part XI launched in 1990, that the UN General Assembly finally adopted the agreement on its implementation. (18)

Some "lacunae" in the Convention are important because they leave the field open to sometimes very divergent interpretations by states, especially when they seek to satisfy their national interests first and foremost. As a result of power rivalries, these "lacunae" continue to fuel deadlocks, as the Sino-American confrontation shows.

\section{China and UNCLOS: Ratification despite reservations and exceptions}

China signed UNCLOS when it opened for signature on 10 December 1982 and ratified it on 15 May 1996. ${ }^{(19)}$

Before its admission to the UN in October 1971, China had a very unfavourable view of the four Geneva Conventions adopted in 1958. For the leaders of the Chinese Communist Party, these agreements were the result of manipulation by the great powers and served their interests over those of the newly independent Third World. Chinese leaders especially criticised the notion of freedom of the high sea, which in their eyes benefited only major Western maritime powers; the criteria for exploitation of the continental shelf, regarded as favouring the more technologically advanced countries; and the right of innocent passage of foreign ships through the territorial sea, which implicitly included military vessels. In this context, China sided with other developing countries in calling for the writing of a new Convention. (20)

During negotiations, when the width of the territorial sea was debated, China opposed from the outset the width of three nautical miles defended

11. Zhang Haiwen, "Is It Safeguarding the Freedom of Navigation or Maritime Hegemony of the United States? - Comments on Raul (Pete) Pedrozo's Article on Military Activities in the EEZ," Chinese Journal of International Law, Vol. 9, 2010, pp. 31-47. When this article was published, Zhang Haiwen was deputy director-general of the China Institute for Marine Affairs (CIMA) and secretary of the Chinese Society of the Law of the Sea.

12. Expression used by Tommy B. Koh, President of the Third Conference of the United Nations Convention on the Law of the Sea, at the time of the closing session of the Conference held in Montego Bay from 6 to 11 December 1982. Quote in David Freestone, "The Law of the Sea Convention at 30: Successes, Challenges and New Agendas," The International Journal of Marine and Coastal Law, Vol. 27, No. 4, 2012, p. 675.

13. In accordance with Paragraph 1 of Article 308 of the Convention, the entry into force came " 12 months after the date of deposit of the sixtieth instrument of ratification or accession" to the Secretary-General of the United Nations Organisation. See United Nations, "United Nations Convention on the Law of the Sea (Full texts)," www.un.org/Depts/los/convention_agreements/texts/ unclos/closindx.htm (accessed on 12 April 2016).

14. There were the "Convention on the Territorial Sea and the Contiguous Zone, 1958," the "Convention on the High Seas, 1958," the "Convention on Fishing and Conservation of the Living Resources of the High Seas, 1958," and the "Convention on the Continental Shelf, 1958."

15. For an evaluation of the Convention following its entry into force, see: "The Law of the Sea Convention: Unfinished Agendas and Future Challenges" (special feature), The International Journal of Marine and Coastal Law, Vol. 10, No. 2, 1995, pp. 157-334. For a later evaluation, corresponding to the $30^{\text {th }}$ Anniversary of its adoption, see another special feature of The International Journal of Marine and Coastal Law, Vol. 27, No. 4, 2012, pp. 675-881.

16. Jaye Ellis, "The Exclusive Economic Zone and the United Nations Convention on the Law of the Sea, 1982-2000," American Journal of International Law, No. 98, 2004, p. 395.

17. See James B. Morell, The Law of the Sea: The 1982 Treaty and Its Rejection by the United States, Jefferson, NC, McFarland and Company, 1992. See also the official statement: Ronald Reagan, "Statement on United States Oceans Policy," 10 March 1983, available on the website of UNCLOS: www.un.org/Depts/los/LEGISLATIONANDTREATIES/PDFFILES/USA_1983_Statement.pdf (accessed on 6 April 2016).

18. United Nations, "Agreement relating to the implementation of Part XI of the United Nations Convention on the Law of the Sea of 10 December 1982 (with annex). Adopted by the General Assembly of the United Nations on 28 July 1994," Treaty Series, Vol. 1836, No. 31364, 1994. Available online at https://treaties.un.org/doc/Publication/UNTS/Volume\%201836/v1836.pdf (accessed on 12 April 2016)

19. The instrument of ratification has been deposed at the United Nations headquarters on 7 June 1996.

20. For a complete presentation of the Chinese positions in the course of negotiations of UNCLOS, see among others Jeanette Greenfield, China's Practice in the Law of the Sea, Oxford, Clarendon Press, 1992, and Gao Zhiguo, "China and the Law of the Sea," in M. Nordquist, T. Koh and J. N. Moore (eds), Freedom of Seas, Passage Rights and the 1982 Law of the Sea Convention, Leiden, Martinus Nijhoff, 2009, pp. 265-277. 
by the American and British naval powers, and defended the idea, with a large majority of states (89 of 116), of a width of 12 nautical miles or more. Like most developing countries, China demanded the establishment of an EEZ with a width of 200 nautical miles after a failed attempt, alongside Peru, to territorialise this maritime jurisdiction by claiming the coastal state's full authority over it. ${ }^{(21)}$ China refused, however, the principle of the median line and equidistance for the delimitation of potential tangles of EEZ between two opposite or adjacent States. Finally, China reiterated concerns regarding the right of innocent passage through the territorial sea, which it wanted to give only to civilian ships, and campaigned for the recognition of exclusive control by the coastal state of marine scientific research inside the EEZ.

In sum, after several years of rivalries and arbitration, China was not fully satisfied with the text concluded in 1982, and at the time of the adoption of the Convention, Han Xu, President of the Chinese delegation, criticised the presence of "shortcomings and even serious defects in the provisions of quite a few articles." (22) The reasons why China immediately signed the Convention on 10 December 1982 were in fact essentially political. In the eyes of Chinese leaders, this new version of UNCLOS, replacing an "old law of the sea which only served the interests of a few big powers," was especially "conducive to the fight against maritime hegemonism." (23) As for the rest, the Chinese authorities maintained their position and continued to oppose certain provisions of the Convention through the enactment of a national maritime legislation, including the "Law on the Territorial Sea and the Contiguous Zone of 25 February 1992 " and the "Exclusive Economic Zone and Continental Shelf Act of 26 June 1998." (24)

\section{The United States and UNCLOS: The permanent question of ratification}

The fact that the first global maritime power still has not, as of April 2016, ratified the UNCLOS while it intends to defend the principles of this international law on the world stage is at first glance surprising. This is even more the case as the United States brought all its influence to bear on the negotiations in obtaining many compromises, ${ }^{(25)}$ and as the main obstacle to its accession, i.e. Part XI on the international seabed zone, was removed with the adoption of the new agreement on 28 July 1994 that it signed quickly. At first sight, this signature logically opened the way for quick ratification. But more than 20 years later, although supported by the respective administration of Clinton, Bush II and Obama, the text of the Convention still has not been voted on by the Senate because it hasn't gotten the necessary $2 / 3$ vote for ratification or because its assessment has been put aside in favour of issues considered more urgent. ${ }^{(26)}$

The Senate's refusal to ratify the UNCLOS is the result of strong opposition from a handful of senators belonging to the most conservative wing of the Republican Party. Their main argument is that the Convention is "inconsistent with American sovereignty and values" and that the US, in the case of ratification, has more to lose than to gain politically and economically. ${ }^{(27)}$ In other words, they believe that their country will not receive any benefit from accession and that it remains quite capable of protecting its maritime interests outside the Convention. (28) Finally, the fact that a number of states, including China, have ratified the text without giving up claims that the United States deemed "excessive" has created doubt over the real value of accepting it.
The contingent supporting ratification is much broader and includes members of both the Democratic and Republican parties, former officers of the US Navy and US Coast Guard, industrial interests (including oil and mining companies), and marine environmental protection associations. (29) According to this side, UNCLOS does not run counter to US national interests. ${ }^{(30)}$ For some political and military players, two factors even make its ratification very urgent: firstly the Arctic, where in the context of the ice melt the United States risks being marginalised in the face of Canadian and Russian claims, and secondly China's recent assertiveness in the South China Sea and in maritime affairs globally, coupled with the rapid modernisation of its navy, which are seen as major challenges in terms of security. (31) Other arguments state that ratification would also help rehabilitate the image of the US, often accused by other states of "despising" international law, a feeling that tends to encourage rather than discourage the "excessive" maritime claims that the United States is trying to fight in East Asia and around the world. ${ }^{(32)}$ According to the Convention's supporters, this would facilitate new states joining in maritime security operations such as the Proliferation Security Initiative (PSI), which China and some other countries such as Indonesia do not consider legal because it is conducted under the command of a state that is not a party to the Convention. ${ }^{(33)}$

Pending a possible though very hypothetical future ratification, the United States continues to work outside the Convention, a number of the clauses of which it nevertheless implements. It thus established an EEZ of 200 nautical miles in 1983, extended its territorial sea from an initial width of three nautical miles to one of 12 nautical miles in 1988, and added to it a con-

21. Raul (Pete) Pedrozo, "A Response to Cartner's and Gold's Commentary on 'Is it Time for the United States to Join the Law of the Sea Convention?'," Journal of Maritime Law \& Commerce, Vol. 42, No. 4, October 2011, p. 497

22. Declaration of Han Xu, President of the Chinese delegation at the time of the third Conference of the UNCLOS, made following the adoption of the Convention, quoted in Jeanette Greenfield, China's Practice in the Law of the Sea, op. cit., p. 203.

23. Ibid.

24. The texts of these two laws are available on the page "China" of the website of the United Nations Division of Oceanic Affairs and the Law of the Sea: http://www.un.org/Depts/los/LEGISLATIONANDTREATIES/STATEFILES/CHN.htm (accessed on 20 April 2016).

25. For example, regarding the creation of the EEZ, the United States, worried that this new regulation would remove from the high sea $1 / 3$ of the total marine area, insisted on maintaining freedom of navigation in the EEZ. See Steven D. Vincent, "China and the United Nations Convention on the Law of the Sea: Operational Challenges," Final Report, Newport, Naval War College, 2005, p. 2.

26. Yann-Huei Song and N. Elias Blood-Patterson, "Likelihood of U.S. Becoming a Party to the Law of the Sea Convention During the $112^{\text {th }}$ Congress," Journal of Maritime Law \& Commerce, Vol. 43, No. 4, October 2012, p. 457

27. For an overview of the arguments opposed to the ratification, see "Why the 'Law of the Sea Treaty' is Still a Bad Idea," published by the association Heritage Action for America, affiliated with the Heritage Foundation, a conservative think tank based in Washington, http://heritageaction.com/ stoplost/why-the-law-of-the-sea-treaty-is-still-a-bad-idea (accessed on 14 April 2016).

28. Raul (Pete) Pedrozo, "A Response to Cartner's and Gold's Commentary on 'Is It Time for the United States to Join the Law of the Sea Convention?'," art. cit., p. 500 and pp. 509-510.

29. Brian Wilson and James Kraska, "American Security and Law of the Sea," Ocean Development \& International Law, Vol. 40, 2009, p. 269.

30. US Council of Foreign Relations, "Should the United States Ratify the UN Law of the Sea?", question asked by Jason Thomas to John B. Bellinger, Adjunct Senior Fellow for International and National Security Law, 11 November 2014, www.cfr.org/treaties-and-agreements/should-unitedstates-ratify-un-law-sea/p31828 (accessed on 14 April 2016).

31. Yann-Huei Song and N. Elias Blood-Patterson, "Likelihood of U.S. Becoming a Party to the Law of the Sea Convention During the $112^{\text {th }}$ Congress," art. cit., pp. 449-452; Michael J. Kelly, "United States Ratification of the Law of the Sea Convention: Securing Our Navigational Future While Managing China's Blue Water Ambitions," Case Western Reserve Journal of International Law, Vol. 45, 2012, p. 463.

32. Zou Keyuan, "Law of the Sea Issues Between the United States and East Asian States," Ocean Development \& International Law, Vol. 39, 2008, p. 86.

33. Brian Wilson and James Kraska, "American Security and Law of the Sea," art. cit., p. 285. 
tiguous zone in 1999. (34) Open to two vast oceans, the United States has the largest EEZ in the world and one of the largest continental shelves. Beyond the initial reluctance that prevented its signature, UNCLOS in fact allows American power to profit from this advantageous geography.

However, the main US concern in terms of international law of the sea regards "excessive" maritime claims that would hamper its right of freedom of navigation and overflight. To counter this, the US authorities in 1979 introduced the "freedom of navigation program," (35) which aims to challenge state practices that in their view are inconsistent with the international law of the sea. Although, as the US Department of Defense reports show, ${ }^{(36)}$ China is not the only state targeted by the "freedom of navigation operations," the assertion of Chinese presence in the South China Sea and the strategic rivalry of the two powers draws attention and media coverage to operations that, if conducted in other maritime areas of the world, would no doubt pass unnoticed.

\section{Sino-US disputes regarding the law of the sea}

Given that the three recent freedom of navigation operations conducted by the US Navy in the South China Sea had the main objective of challenging China's "excessive" maritime claims, (37) what are China's claims, and what are the main points of disagreement between the two countries?

The passage of the USS Lassen within 12 nautical miles of Subi Reef, a lowtide elevation that China reclaimed and developed during the years 2014 and 2015, aimed to refute the possible delimitation by China of a territorial sea around it and thus demand total freedom of navigation. As a natural structure above water at low tide but submerged at high tide, the low-tide elevation is not an island, and thus, in the eyes of UNCLOS and despite reclamation work, cannot have a territorial sea of its own. ${ }^{(38)}$ An exception exists, however, where low-tide elevation is situated wholly or partly within the territorial sea of a state or an island. Article 13 mentions in fact that it may be used as the baseline for measuring the breadth of the territorial sea, thus increasing its size. (39) Now, it happens that Subi Reef is located within 12 miles of Sandy Cay, which could have a territorial sea of its own but which is administered by the Philippines. China, which claims all the islands located in the South China Sea under its sovereignty, nevertheless could consider that it has the right to delineate a territorial sea from Subi Reef.

For its part, the passage of the USS Curtis Wilbur within the limit of 12 nautical miles from Triton Island aimed first to challenge China's establishment of archipelagic baselines, including all the Paracels, which is inconsistent with UNCLOS, ${ }^{(40)}$ and secondly as a reminder of the importance the United States attaches to the right of innocent passage of warships through the territorial sea of other states without prior notification. This question of the right of innocent passage, which also motivated the freedom of navigation operation of 10 May 2016, is one of the main points of disagreement between China and the United States, alongside differing interpretations relating to military activities, especially hydrographic gathering, and marine scientific research in the EEZ. ${ }^{(41)}$

\section{The right of innocent passage through the territorial sea}

If UNCLOS recognises the sovereignty of the coastal state over the territorial sea, this sovereignty is nevertheless incomplete because states have an obligation not to hamper the innocent passage of foreign vessels. ${ }^{(42)}$ The main point of controversy here is the lack of precision regarding the type of vessels involved and whether or not military vessels are included. For many lawyers, this inclusion is implicit, as Article 20 also states, "In the territorial sea, submarines and other underwater vehicles are required to navigate on the surface and to show their flag." (43)

However, although the majority of states that have ratified the Convention recognise, explicitly or implicitly, the right of innocent passage for military vessels through their territorial sea, a number of countries, including China, require advance approval or prior notification. These requirements were at the heart of intense debate during negotiations over the Conventions of 1958 and 1982 but were never accepted due to a lack of consensus and very strong opposition from the United States, the USSR, and their respective allies.

On this issue, China has maintained the position that it took during negotiations. If it recognises a right of innocent passage in its "Law on the Territorial Sea and the Contiguous Zone of 25 February 1992," it nevertheless makes a distinction between military vessels and commercial ships, the former requiring authorisation from the Chinese authorities before entering the Chinese territorial sea. ${ }^{(44)}$ This last point has been strongly criticised by the United States, which considers the establishment of an advance authorisation or prior notification a "hindrance" to innocent passage and therefore inconsistent with Article 24 of the Convention defining obligations of the coastal state. ${ }^{(45)}$

\section{Hydrographic gathering, marine scientific research, and military activities in the EEZ}

The second point of Sino-US controversy concerns hydrographic gathering carried out by military vessels in the EEZ of another state and its difference from marine scientific research. This controversy is partly based on the ab-

34. Declarations and laws relating to these zones are available on the page "United States" of the website of the United Nations Division for Ocean Affairs and the Law of the Sea: www.un.org/Depts/los/LEGISLATIONANDTREATIES/STATEFILES/USA.htm (accessed on 20 April 2016).

35. US Department of Defense, "Freedom of Navigation Program - Fact Sheet," March 2015, http://policy.defense.gov/Portals/11/Documents/gsa/cwmd/DoD\%20FON\%20Program\%20— \%20Fact\%20Sheet\%20\%28March\%202015\%29.pdf (accessed on 5 April 2016).

36. US Department of Defense, "DoD Annual Freedom of Navigation (FON) Reports," http://policy.defense.gov/OUSDPOffices/FON.aspx (accessed on 5 April 2016).

37. "Document: SECDEF Carter Letter to McCain on South China Sea Freedom of Navigation Operation," USNI News, 5 January 2016, https://news.usni.org/2016/01/05/document-secdef-carter-letter-to-mccain-on-south-china-sea-freedom-of-navigation-operation (accessed on 5 April 2016).

38. According to Paragraph 1 of Article 121, an island is "a naturally formed area of land, surrounded by water, which is above water at high tide." Add to this Article 13 on "low-tide elevation," which mentions clearly that these natural structures have "no territorial sea of its own" if they are "wholly situated at a distance exceeding the breadth of the territorial sea from the mainland or an island." See UNCLOS, Article 13, "Low-tide elevations" and article 121 "Regime of islands."

39. UNCLOS, Article 13, "Low-tide elevations."

40. The delimitation of the archipelagic baselines is only permitted for archipelagic states, a category that includes neither China nor the Paracel Islands. See UNCLOS, Article 47, "Archipelagic baselines"; Zou Keyuan, "Law of the Sea Issues Between the United States and East Asian States," art. cit., p. 74.

41. We do not discuss hereafter the issue of the arbitration proceedings initiated by the Philippines in 2013. Whatever its result, to be announced in June-July 2016, this procedure aims to contest China's claims of "historical rights" in the South China Sea. But while the United States supported this initiative, it seemed that it was more to applaud the use of the Permanent Court of Arbitration by the Philippines than to contest Chinese territorial claims.

42. UNCLOS, Article 17, "Right of innocent passage."

43. UNCLOS, Article 20, "Submarines and other underwater vehicles."

44. See Article 6 of the "Law on the Territorial Sea and the Contiguous Zone of the People's Republic of China" of 25 February 1992. This article takes up the content of Article 11 of the "Law on Safety of the Maritime Traffic" of 1983, which stipulates that foreign military ships are not allowed to enter into China's territorial sea without authorisation. See State Oceanic Administration (ed.), Collection of the Sea Laws and Regulations of the People's Republic of China, Beijing, Ocean Press, 2001.

45. This article mentions among other things that the coastal state shall not "impose requirements on foreign ships which have the practical effect of denying or impairing the right of innocent passage." UNCLOS, Article 24, "Duties of the coastal State." 
sence of an exact definition of these two types of activity in the Convention. For its part, the United States makes the distinction between hydrographic gathering, ${ }^{(46)}$ useful for making charts and for the safety of navigation, and marine scientific research that specifically relates to the study of marine environments, including, for example, oceanography and underwater archaeology. ${ }^{(47)}$ From the American point of view, hydrographic gathering falls under the ambit of freedom of navigation and is therefore not subject to the control of the coastal state. This US position is strongly opposed by China, which considers hydrographic gathering activities part of marine scientific research, which according to Article 246 "shall be conducted with the consent of the coastal State." (48) China incorporated the main provisions of Part XIII of UNCLOS on marine scientific research in its "Exclusive Economic Zone and Continental Shelf Act" as well as in its regulations on the management of marine scientific research by foreign vessels, which entered into force on 1 October 1996. ${ }^{(49)}$ In addition, China regulated gathering activities through the enactment in 1992 of a law on surveying and mapping, which subjects any such activity on its territory and in its maritime jurisdiction to the approval of the State Council. (50)

For China, hydrographic gatherings conducted by military ships are not innocent because the data collected can also be used for military purposes. In other words, they may, in its view, represent a threat to the coastal state and should therefore be controlled and regulated by this state. (51) In fact, this disagreement refers to the broader question of whether or not a state can conduct military activities in the EEZ of another state without its consent. While the United States again advocates freedom of navigation as well as "other internationally lawful uses of the Sea," (52) China claims, together with other states, ${ }^{(53)}$ the right of control.

Since these disagreements have provoked incidents in the past, ${ }^{(54)}$ the possibility of new clashes occurring in the EEZs claimed by China cannot be ruled out.

\section{Conclusion}

The positions of China and the United States regarding the law of the sea form a complex topic exceeding the Manichean scheme that would see a country respecting the law of the sea and another one not. Among the main points bringing China and the United States into opposition, some Chinese positions, such as on the right of innocent passage, appear quite clearly in contradiction to the law of the sea, while others mainly consist of interpretations of incomplete clauses or undefined terms.

The practice of both countries brings further complexity to the issue. While China's reclamation work and building of infrastructure on the disputed Spratly Islands, like that undertaken before and at the same time by the Philippines, Taiwan, and Vietnam, goes against a certain "self-restraint," the strict implementation by China of its national laws in terms of right of innocent passage through its territorial sea and of foreign military activities in its claimed EEZ remains to be assessed. In the case of the three freedom of navigation operations that the United States conducted in October 2015, January 2016, and May 2016, the Chinese authorities protested, first verbally, and then by sending fighter jets and warships, but did not intercept or board American ships. ${ }^{(55)}$

On both sides, UNCLOS, whatever its flaws, has been taken hostage by ideological, political, and geostrategic considerations. On the US side, whether or not the country is an integral part of the Convention, the objective is quite clearly to oppose the naval ambitions of China. ${ }^{(56)}$ The three aforementioned FONOPs may have been motivated more by the changing geostrategic environment in the South China Sea, marked by a strengthening of the Chinese presence, than by the single objective of fighting against "excessive" maritime claims. Faced with Chinese initiatives, an American response was actually expected and desired in the US Senate as well as by some US allies such as Japan and the Philippines. ${ }^{(57)}$ As such, in light of the concern, debate, and discontent that the deployment of missile launchers on Woody Island created within the American political scene, ${ }^{(58)}$ the announcement almost immediately afterwards by some US officials that new FONOPs would be conducted in the South China Sea - an intention confirmed by the operation in May 2016 - is therefore not surprising and confirms the interaction between the international law of the sea and the defence of strategic interests. ${ }^{(59)}$

Finally, the historical background clearly shows that current disagreements date back to the time of the negotiations and the writing of the law of the sea, in the course of which China, a developing country and a coastal state, was concerned about its security and committed to increasing its sovereign rights over maritime areas, while at the same time fighting "US maritime hegemony." On China's side, is this inherited pattern likely to evolve at a

46. These data generally refer to depth, the configuration and the nature of the seabed, the direction and the strength of the currents, the amplitude and duration of the tides, and the location of topographic features and fixed objects.

47. Sam Bateman, "Hydrographic Surveying in the EEZ: Differences and Overlaps with Marine Scientific Research," Marine Policy, Vol. 29, 2005, p. 167.

48. UNCLOS, Article 246, "Marine Scientific Research in the Exclusive Economic Zone and on the Continental Shelf."

49. Moritaka Hayashi, "Military Activities in the Exclusive Economic Zones of Foreign Coastal States," The International Journal of Marine and Coastal Law, Vol. 27, No. 4, 2012, p. 798.

50. Following a 29 August 2002 amendment, these activities must now be conducted in cooperation with a Chinese partner and also submitted to the approval of the armed forces. See Moritaka Hayashi, "Military Activities in the Exclusive Economic Zones of Foreign Coastal States," art. cit., pp. 798-799.

51. Steven D. Vincent, "China and the United Nations Convention on the Law of the Sea: Operational Challenges," art. cit., p. 8.

52. UNCLOS, Article 58, "Rights and duties of other States in the exclusive economic zone."

53. Bangladesh, Brazil, Cap Verde, North Korea, India, Indonesia, Iran, Kenya, Malaysia, Maldives, Mauritius, Myanmar, Pakistan, and Uruguay also oppose the US view and do not allow some foreign military activities in their EEZ without their consent. Raul (Pete) Pedrozo, "A Response to Cartner's and Cold's Commentary on 'Is it Time for the United States to Join the Law of the Sea Convention?'," art. cit., p. 497.

54. These include the collision between a US surveillance plane and a Chinese fighter over the EEZ of Hainan in April 2001, the interception of the USNS Bowditch, a hydrographic survey vessel of the US Navy, by the Chinese armed forces in the Yellow Sea in September 2002, and harassment of the USNS Impeccable by vessels of the Chinese Navy, Coast Guard, and Maritime Militia in the Hainan EEZ in March 2009.

55. Regarding the case of the operation of October 2015, see: "DM Spokesman: China Firmly Opposes U.S. Warship's Patrol in Nansha," China Military Online, 28 October 2015, article available on the website of China's ministry of Defense: http://eng.mod.gov.cn/DefenseNews/2015-10/28/content_4626256.htm (accessed on 5 April 2016); "China Says US warship's Spratly Islands Passage 'Illegal'," BBC News, 27 October 2015, www.bbc.com/news/world-asia-china-34647651 (accessed on 5 April 2016).

56. See Wen-Lung Laurence Lin, "America's South China Sea Policy, Strategic Rebalancing, and Naval Diplomacy," Issues \& Studies, Vol. 29, No. 4, December 2013, pp. 189-228.

57. Jake Douglas, "How the Rest of Asia Reacted to US Navy Patrol Near China's Man-Made Island," The Diplomat, 28 October 2015, http://thediplomat.com/2015/10/how-the-rest-of-asia-reactedto-us-navy-patrol-near-chinas-man-made-island/?utm_content=buffer57809\&utm_ medium=social\&utm_source=facebook.com\&utm_campaign=buffer (accessed on 6 April 2016).

58. Naoya Yoshino, "Chinese Missiles Put Obama Administration Under Fire," Nikkei Asian Review, 19 February 2016, http://asia.nikkei.com/Politics-Economy/Policy-Politics/Chinese-missiles-putObama-administration-under-fire (accessed on 7 April 2016).

59. David Smith, "South China Sea Dispute: US Military Will Continue Operations in Region," The Guardian, 17 February 2016, www.theguardian.com/world/2016/feb/17/south-china-sea-dispute-us-military-operations-china-island-barack-obama-white-house (accessed on 5 April 2016); Ankit Panda, "South China Sea FONOP No. 3: Coming Soon?", The Diplomat, 4 April 2016, http://thediplomat.com/2016/04/south-china-sea-fonop-no-3-coming-soon (accessed on 7 April 2016). 
time when the Chinese authorities are seeking to turn the country into a global maritime power? Will the ongoing construction of a deep-sea fleet and its ultimate goal to sail beyond the China Seas push Chinese leaders to espouse American positions regarding, for example, total freedom of navigation, as some recent events suggest? ${ }^{(60)}$ This is a vast field that deserves wider analysis. We can also note that there is ongoing debate in China about the law of the sea and that in this context some lawyers, such as Mincai Yu, advocate the abolition, in the laws of 1983 and 1992, of the distinction between warships and civilian vessels and the authorisation of the right of innocent passage to all ships. According to Mincai Yu, the only option for China to meet the challenges posed by the United States would be to transform its traditional position as a coastal state into that of a maritime power and consider the revision of national laws with provisions inconsistent with the UNCLOS. ${ }^{(61)}$ At a time when the Chinese authorities are putting in place maritime courts with the stated goal of "protecting the sovereignty and maritime rights in their countries," (62) will there be room for such debate? In any case, the impact of such a creation on the perception and implementation of the law of the sea by China are potentially important and undoubtedly deserve to be analysed in the near future.

ISébastien Colin, associate professor at INALCO, Paris, has been on assignment at CEFC as researcher and deputy chief editor of China Perspectives since 1 September 2014

(sebastien.colin@cefc.com.hk).
60. On 4 September 2015, after holding joint military exercises with Russia, five Chinese Navy ships sailed within the US territorial sea near the Aleutian Islands without prior notification. See Jeremy Page and Gordon Lubold, "Chinese Navy Ships Came Within 12 Nautical Miles of U.S. Coast," The Wall Street Journal, 4 September 2015, www.wsj.com/articles/chinese-navy-ships-off-alaskapassed-through-u-s-territorial-waters-1441350488 (accessed on 18 May 2016).

61. Mincai Yu, "China Being A Maritime Power under the UNCLOS: Issues and Ways Ahead," Journal of East Asia and International Law, Vol. VII, No. 2, 2014, pp. 313 and 334. On the opposite side, there is another vision (in the minority) in favour of denouncing and leaving UNCLOS.

62. Susan Finder, "China's Maritime Courts: Defenders of 'Judicial Sovereignty'," The Diplomat, 5 April 2016, http://thediplomat.com/2016/04/chinas-maritime-courts-defenders-of-judicial-sovereignty (accessed on 12 April 2016). 